\title{
PRESENCE OF RESPIRATORY VIRUSES IN EQUINES IN BRAZIL
}

\author{
Dalva Assunção Portari MANCINI(1), Aparecida Santo Pietro PEREIRA(1), Rita Maria Zucatelli MENDONÇA(1), Adelia Hiroko Nagamori KAWAMOTO(1), \\ Rosely Cabette Barbosa ALVES(1), José Ricardo PINTO(1), Enio MORI(2), Leonardo José RICHTZENHAIN(2) \& Jorge MANCINI-FILHO(3)
}

\begin{abstract}
SUMMARY
Equines are susceptible to respiratory viruses such as influenza and parainfluenza. Respiratory diseases have adversely impacted economies all over the world. This study was intended to determine the presence of influenza and parainfluenza viruses in unvaccinated horses from some regions of the state of São Paulo, Brazil. Blood serum collected from 72 equines of different towns in this state was tested by hemagglutination inhibition test to detect antibodies for both viruses using the corresponding antigens. About $98.6 \%$ (71) and $97.2 \%$ (70) of the equines responded with antibody protective titers $(\geq 80 \mathrm{HIU} / 25 \mu \mathrm{L}) \mathrm{H}_{7} \mathrm{~N}_{7}$ and $\mathrm{H}_{3} \mathrm{~N}_{8}$ subtypes of influenza A viruses, respectively. All horses (72) also responded with protective titers $(\geq 80) \mathrm{HIU} / 25 \mu \mathrm{L}$ against the parainfluenza virus. The difference between mean antibody titers to $\mathrm{H}_{7} \mathrm{~N}_{7}$ and $\mathrm{H}_{3} \mathrm{~N}_{8}$ subtypes of influenza A viruses was not statistically significant $(p>0.05)$. The mean titers for influenza and parainfluenza viruses, on the other hand, showed a statistically significant difference $(p<0.001)$. These results indicate a better antibody response from equines to parainfluenza 3 virus than to the equine influenza viruses. No statistically significant differences in the responses against $\mathrm{H}_{7} \mathrm{~N}_{7}$ and $\mathrm{H}_{3} \mathrm{~N}_{8}$ subtypes of influenza $\mathrm{A}$ and parainfluenza 3 viruses were observed according to the gender (female, male) or the age ( $\leq 2$ to 20 years-old) groups. This study provides evidence of the concomitant presence of two subtypes of the equine influenza $\mathrm{A}\left(\mathrm{H}_{7} \mathrm{~N}_{7}\right.$ and $\left.\mathrm{H}_{3} \mathrm{~N}_{8}\right)$ viruses and the parainfluenza 3 virus in equines in Brazil. Thus, it is advisable to vaccinate equines against these respiratory viruses.
\end{abstract}

KEYWORDS: Parainfluenza virus; Influenza virus; Serology; Hemagglutination inhibition test; Equines.

\section{INTRODUCTION}

Influenza is a contagious disease caused by negative eight-stranded RNA viruses of the Orthomyxoviridae family. There are three major types: A, B and C. Influenza A viruses are further classified into subtypes - 16 HA and 9 NA - according to the nature of the viral envelope glycoprotein: hemagglutinin $(\mathrm{H})$ or neuraminidase $(\mathrm{N})$. Influenza A viruses stand out because they are able to infect both humans and animals, which characterizes influenza as a zoonotic disease. Also, their $\mathrm{H}$ and $\mathrm{N}$ antigens undergo considerable variations, unlike the same proteins in types $\mathrm{B}$ and $\mathrm{C}$, which display minor alterations. Outbreaks of influenza type A occur in outbreaks in late fall and all over the winter season. Pandemics caused by influenza type A viruses frequently strike human populations ${ }^{1,12,19}$.

They target different cell types across species - strains of human $\left(\mathrm{H}_{1}\right.$ and $\left.\mathrm{H}_{3}\right)$ and equine $\left(\mathrm{H}_{3}\right.$ and $\left.\mathrm{H}_{7}\right)$ viruses, for example, attach to receptors on tracheal epithelial cells, whereas avian influenza viruses attach to cells in the intestine ${ }^{23,25}$.

Equine influenza A viruses (EIV) of subtype $\mathrm{H}_{3} \mathrm{~N}_{8}$ have circulated among horses in Brazil since its isolation by Mc QUEEN et al. ${ }^{10}$, whereas subtype $\mathrm{H}_{7} \mathrm{~N}_{7}$ viruses, isolated in $1976^{2,18}$, are apparently extinct or circulate at low levels in equine populations ${ }^{24}$, which is consistent with recent observations by HEINEMANN et al. ${ }^{8}$, who reported serologic evidence of the $\mathrm{H}_{7} \mathrm{~N}_{7}$ subtype of equine influenza $\mathrm{A}$ virus circulation in the north of Brazil. PENA et al. ${ }^{16}$ noted the presence of the equine $\mathrm{H}_{3} \mathrm{~N}_{8}$ influenza $A$ virus in $35.9 \%$ of 1,592 unvaccinated equines from farms situated in the south of the state of Pará-Brazil. DIEL et al. ${ }^{5}$ have reported the prevalence of antibodies against equine influenza (EIV) viruses among equines in Rio Grande do Sul (RS), Brazil: 986 sera samples from 1,506 equines $(65.4 \%)$ revealed positivity for them. Recently, TONG et al. ${ }^{21}$ have isolated a new influenza A virus from little yellow-shouldered bats captured in two different locations in Guatemala and named it as $\mathrm{H}_{17}$. This virus lineage differs in genetic constitution from all other known influenza A viruses, but it was not recognized as a new $\mathrm{H}$ subtype until now.

The acute respiratory disease caused by the equine influenza virus (EIV) features high morbidity and low mortality. The symptoms are: high temperature $\left( \pm 38^{\circ} \mathrm{C}\right)$, anorexia, coughing, dyspnea, nasal discharge and, depression. In some cases, it can escalate into a bacterial secondary infection (e.g. pneumonia), which may result in the death of the infected horses $^{22}$. The disease also implies economic losses including turf race cancellations, reduced athletic performance in horses and treatment costs. 
MANCINI, D.A.P.; PEREIRA, A.S.P.; MENDONÇA, R.M.Z.; KAWAMOTO, A.H.N.; ALVES, R.C.B.; PINTO, J.R.; MORI, E.; RICHTZENHAIN, L.J. \& MANCINI FILHO, J. - Presence of respiratory viruses in equines in Brazil. Rev. Inst. Med. Trop. Sao Paulo, 56(3): 191-5, 2014.

Human parainfluenza viruses belong to the family Paramyxoviridae (Paramyxovirus genus), and are classified into four species: 1, 3 (Respirovirus genus), 2, 4a and 4b (Rubulavirus genus). Human parainfluenza 3 virus is a negative stranded RNA virus of the Respirovirus genus ${ }^{7}$.

They thrive worldwide, in temperate and tropical climates, all year round, through all seasons however, outbreaks of parainfluenza occur in late fall and early winter. Parainfluenza viruses present $\mathrm{HN}$ glycoproteins inserted in their envelopes, exhibiting hemagglutin $(\mathrm{H})$ and neuraminidase (N) features. In addition to infecting both humans and animals, influenza and parainfluenza viral infections share most of their symptoms. Some of the respiratory tract complications associated with the parainfluenza virus infection are: legionellosis, viral pneumonitis, pneumococcal pneumonia, melioidosis ${ }^{11}$.

In the latter half of 1994, a new respiratory virus, a member of the Parainfluenza family, emerged in Australia and appears to be the cause of an infectious disease of zoonotic nature, which has been responsible for the deaths of humans and horses, two humans and 16 horses had died before $1998^{15}$. The authors suggested that the horses may have been infected from contact with infected birds and bats. The autopsy of these infected organisms revealed congested and hemorrhagic lungs, the microscopic lung examination revealing alveolitis with giant cells, and some syncytial formation. Sequenced analysis showed that PCR products from this virus isolated from the horses and one patient were identical. The phylogenetic analysis of the matrix protein segments indicated that this virus was related to other Paramyxoviridae. Fatal encephalitis has been reported in equines infected by a novel paramyxovirus ${ }^{14}$.

PHILBY et al. ${ }^{17}$ proposed menangle virus as a common name for an apparently new virus in the Paramyxoviridae family, isolated from stillborn piglets, in Australia. Sera from humans exposed to infected pigs and fruit bats also revealed seropositivity to these viruses. Additionally, CHANT et al. ${ }^{3}$ presented strong evidence of human infection by the same virus, transmitted to humans by infected pigs, but they were unable to explain the transmission mode.

FIELD et $a l .{ }^{6}$ have reviewed a recently-identified zoonotic paramyxovirus, the Hendra virus which infects equines and then humans. They suggest minimizing the human contact with its natural host a species of fruit bats (Pteropus genus). Similarly, TAYLOR et al. ${ }^{20}$ reported cases of human infection with Hendra virus through contact with equines infected by fruit bats (natural reservoir). Two patients were followed up after two and six years respectively and no evidence of virus shedding was found.

\section{OBJECTIVE}

This work was fueled by concerns about the circulation of influenza and parainfluenza viruses among equines. Therefore, it aimed to investigate antibody responses to both viruses in equine serum. This study's objective was to shed new light on the circulation of the influenza and parainfluenza viruses in animals in Brazil.

\section{MATERIAL AND METHODS}

Animals: Seventy-two equines from stud farms situated in Pirassununga (39), Águas de Lindóia (25) and Mairiporã (08), three cities in the state of São Paulo, Brazil, were selected for blood serum analysis (Fig. 1).

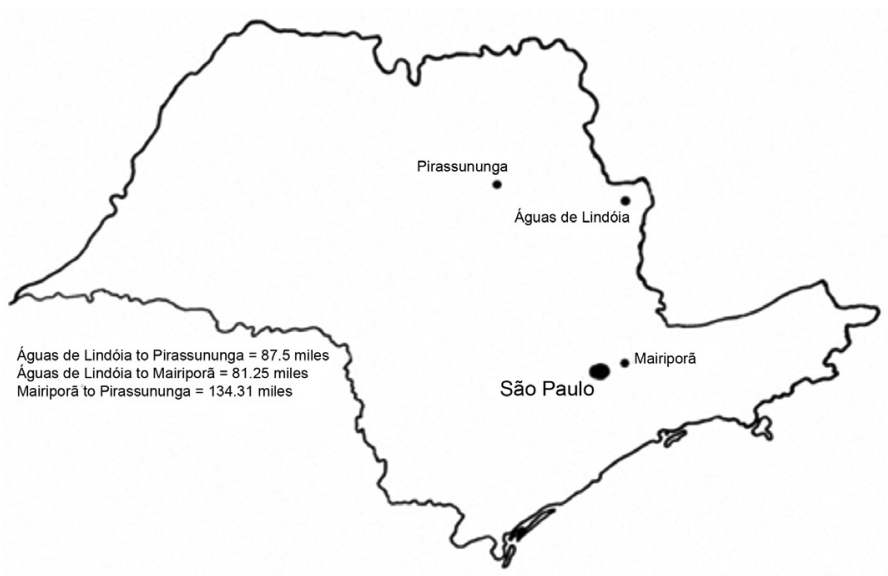

Fig. 1- Location of Pirassununga, Águas de Lindóia and Mairiporã cities in the state of São Paulo, Brazil.

The age, gender and breed of the equines from each city are described as follows:

1) Pirassununga city - 19 equines between five and 10 years old, 14 between 11 and 18 years old and six of an unknown age. Eleven were males and 28 females. As for the breed, 12 were Brazilian Turf, four were Pure Blood Arabian, six were Appaloosa, two were Pêga, five were Breton, one was Brazilian, one Schemule, one was Lusitano. Six of them were of an undefined breed.

2) Águas de Lindóia city - 18 equines between $\leq 2$ and 10 years old, seven between 11 and 20 years old. Seventeen equines were males and eight females. Twelve animals were Mangalarga Paulista, nine were Mangalarga Mineiro; one was Appaloosa and one was Carapolina. Two of them were of an undefined breed.

3) Mairiporã city - five equines between five and nine years old, three over 10 years old. Seven were males and one was female. As for the breed, three were Arabian, one was Pure Blood English, one was Paint-equine, one was Appaloosa, one was Anglo-Arabian and one was Quarter Horse.

Serum: Blood serum samples were taken, heat-inactivated $\left(56^{\circ} \mathrm{C} / 30 \mathrm{~min}\right)$ and then treated with Kaolin $(20 \%)$ and erythrocytes $(50 \%)$ according to MANCINI et al. ${ }^{9}$, DESHPANDE et al. ${ }^{4}$ and OIEN et al. ${ }^{13}$.

Serology: The hemagglutination inhibition (HI) test was performed according to MANCINI et al. ${ }^{9}$. Four HA units in $25 \mu \mathrm{L}$ of viruses were used. Titers were expressed as hemagglutination inhibition units per 25 $\mu \mathrm{L}$ of sera $(\mathrm{HIU} / 25 \mu \mathrm{L})$.

Antigens: Antigens of the influenza viruses types A/Eq1/SP/56 (A $\mathrm{Eq} 1 \mathrm{H}_{7} \mathrm{~N}_{7}$ ) and $\mathrm{A} / \mathrm{Eq} 2 / 1 / \mathrm{SP} / 85\left(\mathrm{~A} \mathrm{Eq} 2 \mathrm{H}_{3} \mathrm{~N}_{8}\right.$ ) and Parainfluenza 3 virus identified and provided by Adolfo Lutz Institute São Paulo, Brazil were used. These virus samples were grown in MDCK (Madin Darby canine kidney) cell cultures according to MANCINI et al. ${ }^{9}$. 


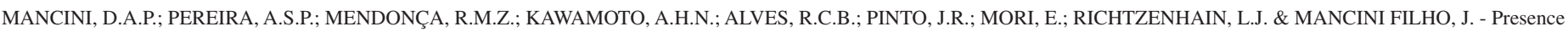
of respiratory viruses in equines in Brazil. Rev. Inst. Med. Trop. Sao Paulo, 56(3): 191-5, 2014.

Table 1

Antibody titers for influenza and parainfluenza viruses in equine sera

\begin{tabular}{|c|c|c|c|c|c|c|c|c|c|}
\hline \multirow{2}{*}{ Virus } & \multirow{2}{*}{ Samples } & \multicolumn{8}{|c|}{$\mathrm{HIU} / 25 \mu \mathrm{L}$} \\
\hline & & $\leq 40$ & 80 & 160 & 320 & 640 & 1280 & 2560 & Total \\
\hline PI & 72 & $-(0)$ & $2.80(02)$ & $16.66(12)$ & $18.05(13)$ & $30.55(22)$ & $25.0(18)$ & $6.94(05)$ & $100(72)$ \\
\hline H7N7 & 72 & $-(0)$ & $20.83(15)$ & $30.55(22)$ & $35.72(25)$ & 11.11(08) & $1.38(01)$ & $-(0)$ & $98.6(71)$ \\
\hline H3N8 & 72 & $-(0)$ & $2.77(02)$ & $29.16(21)$ & $44.44(32)$ & $18.05(13)$ & $2.77(02)$ & $-(0)$ & $97.22(70)$ \\
\hline
\end{tabular}

(HIU = Hemagglutination Inhibition Units).

\section{RESULTS}

The serology results obtained through the hemagglutinating inhibition (HI) test showed that $100,98.6$ and $97.22 \%$ of the equines responded with mean titers of $\geq 80 \mathrm{HIU} / 25 \mu \mathrm{L}$ to parainfluenza 3 and $\mathrm{H}_{7} \mathrm{~N}_{7}$ and $\mathrm{H}_{3} \mathrm{~N}_{8}$ subtypes of influenza A viruses, respectively (Table 1).

Figure 2 depicts the antibody responses to parainfluenza 3 virus in sera, in equines from Pirassununga and Águas de Lindóia and reveals a higher prevalence of the virus in equines from Lindóia city $(\mathrm{HI}=$ 1,324.48) than in the ones from Pirassununga city and from either of the age groups. The difference among mean titers was statistically significant $(p=0.0001)$. Mean HIU/25 $\mu \mathrm{L}$ values for under nine-year-old and over 10-year-old equines, 917.89 and 738.06, respectively, showed no statistically significant difference $(p>0.05)$.

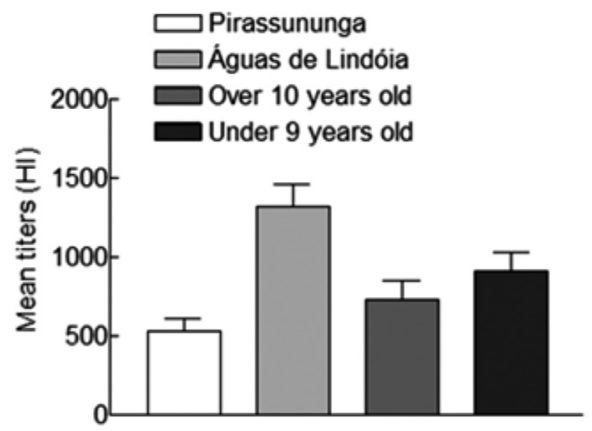

Fig. 2- Antibody response to parainfluenza 3 virus in equines from Pirassununga and Águas de Lindóia cities and in two age groups. The results were expressed as means \pm S.E.M.

Figure 3 depicts the mean titers of influenza A viruses $\left(\mathrm{H}_{7} \mathrm{~N}_{7}\right.$ and $\mathrm{H}_{3} \mathrm{~N}_{8}$ ) for equines over ten years old (HIU/25 $\mu \mathrm{L}$ of 266.35 and 381.93 , respectively). Horses under nine years old showed mean titers $(\mathrm{HIU} / 25 \mu \mathrm{L})$ of 324.67 for influenza $\mathrm{A}\left(\mathrm{H}_{7} \mathrm{~N}_{7}\right)$ and 353.68 for influenza $\mathrm{A}\left(\mathrm{H}_{3} \mathrm{~N}_{8}\right)$. No statistically significant difference was observed.

Overall antibody responses to influenza $\mathrm{A}\left(\mathrm{H}_{7} \mathrm{~N}_{7}\right)$ and $\mathrm{A}\left(\mathrm{H}_{3} \mathrm{~N}_{8}\right)$ viruses and parainfluenza 3 virus were different. No statistically significant difference was observed between both influenza virus subtypes, however the mean titers for influenza and parainfluenza viruses were statistically different $(p<0.01)$ (Table 1$)$.

\section{DISCUSSION}

Serum analysis confirmed the presence of influenza and parainfluenza

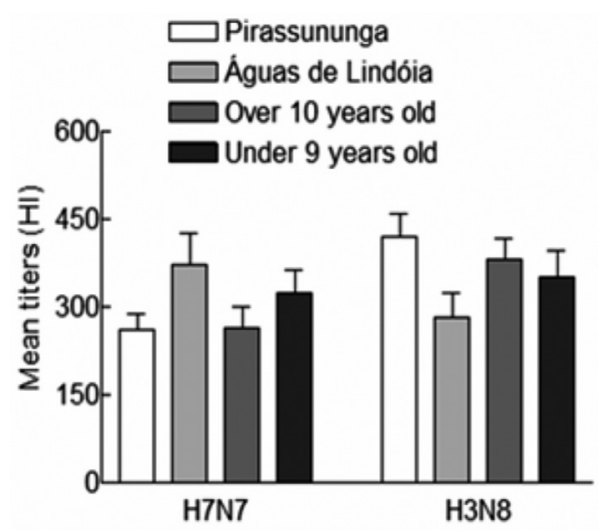

Fig. 3 - Antibody response to influenza A (H7N7) and A (H3N8) viruses in equines from Pirassununga and Águas de Lindóia cities and in two age groups. The results were expressed as means \pm S.E.M.

type 3 viruses, in equines from Pirassununga, Águas de Lindóia and Mairiporã, three cities of the state of São Paulo State, Brazil. The distance between these cities is around $\geq 81.25$ miles therefore, contact between the animals seems very unlikely.

Given that these equines had not been vaccinated against equine influenza or parainfluenza viruses, their antibody responses indicated a viral infection. They may have been infected from contact with infected birds, as previously suggested by PATERSON et al. ${ }^{15}$ (Table I).

Antibody responses, to equine influenza and parainfluenza viruses were not statistically different between the two age groups (equines under nine and over ten years old). Overall, all equines showed greater antibody response to parainfluenza 3 virus than to the equine influenza A viruses $\left(\mathrm{H}_{7} \mathrm{~N}_{7}\right.$ and $\left.\mathrm{H}_{3} \mathrm{~N}_{8}\right)$.

Equines from Águas de Lindóia displayed higher antibody levels $(\mathrm{HIU} / 25 \mu \mathrm{L})$ against parainfluenza 3 virus than against equine influenza viruses, indicating no cross-reactivity among viruses. As for the influenza A viruses, $\left(\mathrm{H}_{7} \mathrm{~N}_{7}\right)$ subtype was more prevalent in the same city than the $\left(\mathrm{H}_{3} \mathrm{~N}_{8}\right)$ subtype, which, in turn, occurred more predominantly in Pirassununga.

The city of Mairiporã provided equines at the smallest sample size and lowest breed diversity. For this reason, it was not used in the comparison analysis of antibody responses.

Outbreaks of equine influenza in Brazil have been reported by 
MANCINI, D.A.P.; PEREIRA, A.S.P.; MENDONÇA, R.M.Z.; KAWAMOTO, A.H.N.; ALVES, R.C.B.; PINTO, J.R.; MORI, E.; RICHTZENHAIN, L.J. \& MANCINI FILHO, J. - Presence of respiratory viruses in equines in Brazil. Rev. Inst. Med. Trop. Sao Paulo, 56(3): 191-5, 2014.

McQUEEN et al..$^{10}$, PIEGAS et al. ${ }^{18}$, CUNHA et al. ${ }^{2}$, PENA et al. ${ }^{16}$ and HEINEMANN et al. ${ }^{8}$, who recently observed the prevalence of equine influenza $\mathrm{A}\left(\mathrm{H}_{7} \mathrm{~N}_{7}\right)$ virus in sera of horses from Uruará, State of Pará, Brazil. DIEL et al. $2005^{5}$ have also reported the prevalence of equine influenza in animals in the south of Brazil.

The zoonotic characteristics of influenza viruses can be attributed to their wide host range, from birds to mammals and even heterothermic animals, as participants in virus circulation ${ }^{1,4,9}$. Fruit bats have also been regarded as a reservoir for both influenza and parainfluenza viruses ${ }^{6,14,17,20}$.

Reports on the development of the parainfluenza 3 virus in equines are scarce, either nationally or internationally. In one relevant study from 1998, in Australia, PATERSON et al. ${ }^{15}$ reported the isolation of a new respiratory virus from horses and humans. Its characterization as a member of the Paramyxovirus genus was initially performed by virological tests and later confirmed by sequence analysis of the PCR products from the virus and the phylogenetic analysis of its matrix. The disease has been responsible for the deaths of human and horses, as observed in recent studies by TAYLOR et al. ${ }^{20}$ and O'SULLIVAN et al. ${ }^{14}$, indicating its zoonotic nature. Equine influenza $\mathrm{A}\left(\mathrm{H}_{7} \mathrm{~N}_{7}\right)$ and $\mathrm{A}\left(\mathrm{H}_{3} \mathrm{~N}_{8}\right)$ viruses are currently common causes of disease in equines and have recently been reported to have infected cats and $\operatorname{dogs}^{1,4,25}$. Considering that these viruses have adversely impacted economies all over the world, it is advisable to vaccinate equines.

In conclusion, our serology results confirmed the wide distribution of respiratory viruses, such as equine influenza and parainfluenza 3 virus, among equines in different cities of the state of São Paulo, Brazil. Because the animals had not been vaccinated against these viruses prior to our study, it is possible to conclude that the equines have been infected by them.

The presence of parainfluenza 3 virus is also evidenced by the fact that this virus is not equine-specific and that no cross-reactions were observed among the viruses studied here.

Further detailed studies of parainfluenza 3 virus infection in equines should be performed in order to develop preventive and protective measures for equine populations in Brazil.

\section{RESUMO}

\section{Presença de vírus respiratórios em equinos do Brasil}

Os equinos são susceptíveis aos vírus respiratórios, como o vírus influenza, e também tem sido citado o vírus parainfluenza. Doenças respiratórias têm impactado a economia em todo mundo. Este estudo intencionou determinar a presença dos vírus influenza e parainfluenza em equinos não vacinados de certas regiões do Estado de São Paulo, Brasil. Os soros coletados de 72 equinos, de diferentes cidades deste Estado, foram submetidos ao teste de Inibição da Hemaglutinação (IH) com objetivo de detectar anticorpos contra os referidos vírus, usando antígenos correspondentes. Cerca de 98,8\% (72) e 97,2\% (70) desses equinos responderam com títulos protetores $(\geq 80 \mathrm{UIH} / 25 \mu \mathrm{L})$ para os subtipos $\mathrm{H}_{7} \mathrm{~N}_{7}$ e $\mathrm{H}_{3} \mathrm{~N}_{8}$ de vírus influenza, respectivamente. Todos equinos (72) responderam com títulos protetores $(\geq 80 \mathrm{UIH} / 25 \mu \mathrm{L})$ contra o vírus parainfluenza 3 . A diferença entre as médias de anticorpos contra o vírus influenza A não foi estatisticamente significante $(p>0,05)$. As médias de títulos dos vírus influenza e parainfluenza, por outro lado, demonstraram diferença estatisticamente significante $(p<0,001)$. Esses resultados indicam melhor resposta de anticorpos pelos equinos ao vírus parainfluenza 3 do que ao vírus da influenza equina. Nenhuma diferença estatística foi observada nas respostas contra os vírus da influenza equina A $\left(\mathrm{H}_{7} \mathrm{~N}_{7}\right.$ e $\left.\mathrm{H}_{3} \mathrm{~N}_{8}\right)$ e parainfluenza 3, com relação ao gênero (fêmeas e machos) e grupo etário ( $\leq 2$ até 20 anos) nos equinos avaliados. Este estudo fornece evidência da presença concomitante dos dois subtipos vírus influenza $\mathrm{A}\left(\mathrm{H}_{7} \mathrm{~N}_{7}\right.$ e $\left.\mathrm{H}_{3} \mathrm{~N}_{8}\right)$ e do parainfluenza 3 em cavalos no Brasil. Portanto, é aconselhável a vacinação dos cavalos contra esses vírus respiratórios.

\section{ACKNOWLEDGMENTS}

The authors acknowledge the financial support of Conselho Nacional de Desenvolvimento Científico e Tecnológico (CNPq Project 471876/2009/2010) and Fundação de Amparo à Pesquisa do Estado de São Paulo (FAPESP- 2011/03234-7).

\section{REFERENCES}

1. Alexander DJ, Brown IH. Recent zoonoses caused by influenza A viruses. Rev Sci Tech. 2000;19:197-225.

2. Cunha RG, da Silva Passos W, Correa do Valle MD. Surto de gripe equina produzido por vírus de influenza A/equil no Estado do Rio de Janeiro, Brasil. Rev Bras Biol. 1978;38:549-54

3. Chant K, Chan R, Smith M, Dwyer DE, Kirkland P. Probable human infection with a newly described virus in the family Paramyxoviridae. The NSW Expert Group. Emerg Infect Dis. 1998;4:273-5.

4. Deshpande MS, Abdelmagid O, Tubbs A, Jayappa H, Wasmoen T. Experimental reproduction of canine influenza virus $\mathrm{H} 3 \mathrm{~N} 8$ infection in young puppies. Vet Ther. 2009;10:29-39.

5. Diel DG, Almeida SR, Weiblen R, Frandoloso R, Anziliero D, Kreutz LC, Groff FH, et al. Prevalência de anticorpos contra o vírus da influenza, da artrite viral e herpes vírus em equinos do Estado do Rio Grande do Sul, Brasil. Ciên Rural. 2006;36:1467-73.

6. Field HE, Mackenzie JS, Daszak P. Henipaviruses: emerging paramyxoviruses associated with fruit bats. Curr Top Microbiol Immunol. 2007;315:133-59.

7. Flores EF, editor. Virologia veterinária. Santa Maria: UFSM; 2007. p. 888.

8. Heinemann MB, Cortez A, Lara MC, Cunha EM, Nassar AF, Villalobos EM, et al. Soroprevalência do vírus da influenza equina no município de Uruará, PA, Brasil, Amazônia Oriental. Arq Inst Biol. 2009;76:697-9.

9. Mancini DA, Mendonça RM, Cianciarullo AM, Kobashi LS, Trindade HG, Fernandes W, et al. Influenza em animais heterotérmicos. Rev Soc Bras Med Trop. 2004;37:2049 .

10. McQueen JL, Steele JH, Robinson RQ. Influenza in animals. Adv Vet Sci. 1968;12:285-336.

11. Mufson MA. Parainfluenza viruses, mumps virus and Newcastle disease virus. In: Schmidt N, Emmons RW, editors. Diagnostic procedures for viral, rickettsial and chlamydial infections. $6^{\text {th }}$ ed. Washington: American Public Health Association; 1989. p. 669.

12. Neumann G, Kawaoka Y. Host range restriction and pathogenicity in the context of influenza pandemic. Emerg Infect Dis. 2006;12:881-6. 
13. Oien N, Mattern S, Brozowski J, Teel J, Salmon S. Cross-reactivity to field isolates of canine influenza virus by a killed canine influenza virus $\left(\mathrm{H}_{3} \mathrm{~N}_{8}\right.$, Iowa05) vaccine. Intern J Appl Res Vet Med. 2012;10:14-8.

14. O'Sullivan JD, Allwort AM, Paterson DL, Snow TM, Boots R, Gleeson LJ, et al. Fatal encephalitis due to novel paramyxovirus transmitted from horses. Lancet 1997;349:93-5.

15. Paterson DL, Murray PK, McCormack JG. Zoonotic disease in Australia caused by a novel member of the Paramyxoviridae. Clin Infect Dis. 1998;27:112-8.

16. Pena LJ, Pena DA, Barrios PR, Dale R, Lamego MR, Moraes MP. Levantamento soro-epidemiológico da infecção pelo vírus da anemia infecciosa equina-2 e da influeza equina-2 e do herpesvírus equino-1 em rebanhos do sul do Estado do Pará, Brasil. Braz J Vet Res Anim Sci. 2006;43:537-42.

17. Philbey AW, Kirkland PD, Ross AD, Davis RJ, Gleeson AB, Love RJ, et al. An apparenty new virus (Family Paramyxoviridae) infectious for pigs, humans and fruit bats. Emerg Infect Dis. 1998;4:269-71.

18. Piegas NS, Takimoto S, Barbosa HH, Lacerda JP, Guarnieri R, Ishimaru T. Isolamento de vírus influenza em surto de gripe equina em São Paulo. In: Anais do $15^{\circ}$ Congresso Brasileiro de Medicina Veterinária. Rio de Janeiro; 1976. p. 122.
19. Taubenberger JK, Morens DM. Influenza: the once and future pandemic. Public Health Rep. 2010;125(Suppl 3):16-26.

20. Taylor C, Playford EG, McBride WJ, McMahon J, Warrilow D. No evidence of prolonged Hendra virus shedding by 2 patients, Australia. Emerg Infect Dis. 2012;18:2025-7.

21. Tong S, Li Y, Rivailler P, Conrardy C, Castillo DA, Chen LM. A distinct lineage of influenza from bats. Proc Natl Acad Sci U.S.A. 2012;109:4269-74

22. Van Maanen C, Cullinane A. Equine influenza virus infections: an update. Vet Q 2002;24:79-98.

23. Van Riel D, Munster VJ, de Wit E, Rimmelzwaan GF, Fouchir RA, Osterhaus AD, et al. Human and avian influenza viruses target different cells in the lower respiratory tract of humans and other mammals. Am J Pathol. 2007;171:1215-23.

24. Webster RG. Are equine 1 influenza viruses still present in horses? Equine Vet J. $1993 ; 25: 537-8$

25. Webster RG, Shortridge KF, Kawaoka Y. Influenza: interspecies transmission an emergence of new pandemics. FEMS Immunol Med Microbiol. 1997;18:275-9.

Received: 24 October 2012

Accepted: 25 October 2013 